Relations industrielles

Industrial Relations

\title{
Structure du Congrès du Travail du Canada
}

Volume 12, numéro 1-2, janvier-avril 1957

URI : https://id.erudit.org/iderudit/1022604ar

DOI : https://doi.org/10.7202/1022604ar

Aller au sommaire du numéro

Éditeur(s)

Département des relations industrielles de l’Université Laval

ISSN

0034-379X (imprimé)

1703-8138 (numérique)

Découvrir la revue

Citer ce document

(1957). Structure du Congrès du Travail du Canada. Relations industrielles /

Industrial Relations, 12(1-2), 154-154. https://doi.org/10.7202/1022604ar

Tous droits réservés @ Département des relations industrielles de l’Université Laval, 1957
Ce document est protégé par la loi sur le droit d'auteur. L'utilisation des services d'Érudit (y compris la reproduction) est assujettie à sa politique d'utilisation que vous pouvez consulter en ligne.

https://apropos.erudit.org/fr/usagers/politique-dutilisation/ 


\section{STRUCTURE DU CONGRES DU TRAYAIL DU CANADA}

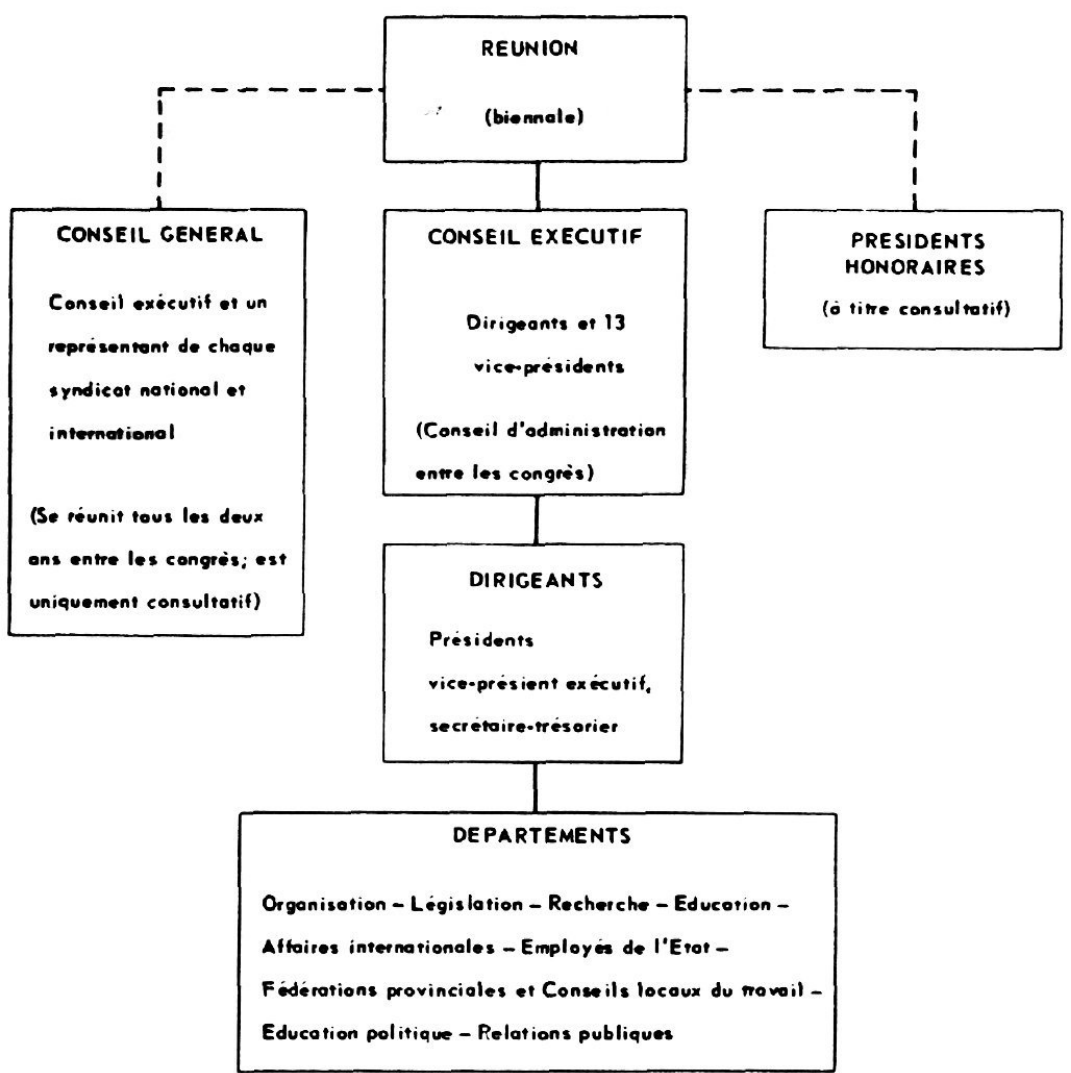

Source: CLC News, ovril 1950. 